\title{
THE DETENTION OF CHILDREN IN ASYLUM PROCEDURES IN EUROPE: REGULATORY FRAMEWORK AND ALTERNATIVES'
}

\author{
Irena Drdúlová, Václav Stehlík \\ Palacký University in Olomouc, Faculty of Law
}

\begin{abstract}
The article focuses on the regulation of the detention of children in asylum procedures in Europe with a special focus on EU law. It clarifies the framework of both international and European regulation, relevant case-law of the European Court of Human Rights and EU Court of Justice as well as soft law instruments adopted in this area. The article discusses grounds for detention, the requirements of necessity and proportionality, procedural safeguards as well as the dignity and human conditions in detention. A special attention is paid to the alternatives to detention, including detention of unaccompanied or separated children or families with children. It adds examples of the good practice.
\end{abstract}

Keywords: detention of children, alternatives to detention, best interest of a child, asylum procedure, Reception Directive, Return Directive

\section{$1 \quad$ INTRODUCTION}

The detention of migrant children - that is detention of children in asylum as well as return procedures - has become a crucial issue especially during the most recent migration wave that started in 2015. However, the detention was not a new topic and had been in the focus of international, EU and national regulation well before. When deciding on the rights of migrant children and their potential detention, the EU Member States are bound by their international law obligations as well as obligations rooted in the European Convention on Human Rights ${ }^{2}$ and, subsequently, the case law of the European Court of Human Rights (ECtHR). Finally, the EU members are obliged to respect the EU regulation and are bound to properly apply it and implement it in their national legal orders. ${ }^{3}$

Preliminarily it should be noted that although detention of migrant children is not explicitly excluded either by the international or European rules, there is a strong tendency among states not to have recourse to these measures that put the principle of best interest of migrant children and their families to a serious risk. Correspondingly, the EU Member States should take into consideration alternatives to child detention which are formulated in various soft law documents.

The article will first analyse the international as well as the EU regulatory framework on detention of children in asylum procedures and then present the mostly available alternatives to such a detention in asylum procedures.

1 Irena Drdúlová participated in the work on this paper on behalf of project „Status of children in EU asylum law“, IGA_ PF_2017_006. Václav Stehlík participated in the work on this paper on behalf of project GACR, "Status of third country nationals in EU law", GA17-24822S.

2 European Convention on Human Rights. Available at: https://www.echr.coe.int/Pages/home.aspx?p=basictexts \& c (accessed on $5^{\text {th }}$ November 2018).

3 For a survey see for example BARRETO, Th. R.: Human Rights of Refugee Children in Light of Multilevel System. Europa-Kolleg Hamburg, Institute for European Integration, Study Paper No 02/18, 2018, p. 19. 


\section{REGULATORY FRAMEWORK TO THE DETENTION OF CHILDREN IN ASYLUM PROCEDURES}

\subsection{Universal instruments}

The detention of children must be discussed in the context of the generally accepted human rights perspective, namely that individuals, including children, have the right to liberty and security and any improperly justified detention is in breach thereof. At the universal level this is regulated especially by the International Covenant on Civil and Political Rights, ${ }^{4}$ International Covenant on Economic, Social and Cultural Rights ${ }^{5}$ and Convention relating to the Status of Refugees. ${ }^{6}$ In that regard a special status is held by the Convention on the Rights of the Child ${ }^{7}$ as it specifically regulates standards of protection of children and their rights. According to the Convention, no child may be deprived unlawfully or arbitrarily of liberty and any arrest, detention or imprisonment of a child must be in conformity with the law and serve as a measure of last resort and for the shortest appropriate period of time. ${ }^{8}$ Thus, although the Convention does not prohibit a child detention, it allows it only as a last resort measure. This requirement is supported by the documents issued by the UN Committee on the Rights of the Child, ${ }^{9}$ UN Office of High Commissioner for Human Rights, ${ }^{10}$ as well as the UN High Commissioner for Refugees. ${ }^{11}$

According to the UN Committee on the Rights of the Child the states should adopt alternatives to detention that would fulfil the best interests of the child. The aim is to allow children to remain with family members and/or guardians if they are present in the transit and/or destination countries and be accommodated as a family in non-custodial, community-based contexts while their immigration status is being resolved. ${ }^{12}$ Furthermore, the unaccompanied children are entitled to special protection and assistance by the state in the form of alternative care and accommodation in accordance with the Guidelines for the Alternative Care of Children. ${ }^{13}$ Furthermore the Working Group on Arbitrary Detention concluded that due to existence of alternatives to detention it is hard

\footnotetext{
Available at: https://www.ohchr.org/en/professionalinterest/pages/ccpr.aspx (accessed on $5^{\text {th }}$ November 2018). Available at: https://www.ohchr.org/en/professionalinterest/pages/cescr.aspx (accessed on $5^{\text {th }}$ November 2018) Available at: https://www.unhcr.org/1951-refugee-convention.html (accessed on $5^{\text {th }}$ November 2018).

Available at: https://www.ohchr.org/en/professionalinterest/pages/crc.aspx (accessed on $5^{\text {th }}$ November 2018).

See art. 37, letter b) of the Convention on the Rights of the Child.
}

9 UN Committee on the Rights of the Child (CRC), Committee on the Rights of the Child, Report of the 2012 Day of General Discussion on the Rights of All Children in the Context of International Migration, 28 September 2012, para. 79.

10 UNGA resolution, A/HRC/31/35, Situation of migrants in transit, Report of the Office of the United Nations High Commissioner for Human Rights, para. 44-45.

11 UN High Commissioner for Refugees (UNHCR), Guidelines on the Applicable Criteria and Standards relating to the Detention of Asylum-Seekers and Alternatives to Detention, 2012.

12 See in full in UN Committee on the Protection of the Rights of All Migrant Workers and Members of Their Families (CMW), Joint general comment No. 4 (2017) of the Committee on the Protection of the Rights of All Migrant Workers and Members of Their Families and No. 23 (2017) of the Committee on the Rights of the Child on State obligations regarding the human rights of children in the context of international migration in countries of origin, transit, destination and return, 16 November 2017, CMW/C/GC/4-CRC/C/GC/23, para. 11.

13 UN Committee on the Rights of the Child (CRC), General comment No. 6 (2005), Treatment of Unaccompanied and Separated Children Outside their Country of Origin, 1 September 2005, CRC/GC/2005/6, paras. 39-40. The guidelines are available at: https://www.unicef.org/protection/alternative_care_Guidelines-English.pdf (accessed on $5^{\text {th }}$ November 2018). 
to imagine a situation when an unaccompanied child could be detained under the conditions set up in art. 37 letter b) of the Convention on the Rights of the Child. ${ }^{14}$

This consensus later spread out to the children who have been detained together with their families. Thus, even if the child is accompanied by the family, he or she should not be detained if the best interests require it. Consequently, states are bound to look for alternatives to detention also for the parents of the child and authorities are obliged to look for solutions not including detention. ${ }^{15}$

A similar conclusion was reached by the UN Commission for Human Rights in the context of interpretation of the arbitrary arrest or detention in art. 9, para 1 of the International Covenant on Civil and Political Rights. The Commission on Human Rights noted that the detention may not be justified if there exist less invasive means of achieving the same ends. This includes for example the imposition of reporting obligations, sureties or other conditions. ${ }^{16}$

\subsection{Council of Europe}

In cases concerning child detention the ECtHR refers most often to art. 3 of the European Convention (prohibition of torture), art. 5 (right to liberty and security) and art. 8 (right to respect for private and family life). The detention of a child in the asylum procedure is not explicitly covered by any provision of the Convention. Still, the ECtHR applies quite rigid criteria when deciding cases concerning detention of migrant children.

The ECtHR case law was reflected also in a resolution on unaccompanied children in Europe issued by the Parliamentary Assembly of the Council of Europe (PACE) ${ }^{17}$ The resolution, as a not binding document, enumerates fifteen common substantive and procedural principles. PACE recommended Member States of the Council of Europe to follow these principles and to set up cooperation for their fulfilment. One of the principles focuses on the situation of an unaccompanied child. It proclaims that no child should be detained based on migration grounds and such a detention should be replaced with appropriate alternative care, preferably foster care. In case of necessity to detain the child in a centre, the child must be separated from adults. ${ }^{18}$ In 2015 the PACE Committee for Migration, Refugees and Displaced Persons spread the principles also in relation to children that were detained together with their families. ${ }^{19}$

\subsection{European Union law - systematic framework}

The EU deals with the detention and its alternatives in its secondary law that formulates an obligation of EU Member States to analyse the possibility to use alternatives to detention before they

14 UNGA, Report of the Working Group on Arbitrary Detention, 18 January 2010, A/HRC/13/30, para. 60.

15 Cf. UN Committee on the Protection of the Rights of All Migrant Workers and Members of Their Families (CMW), Joint general comment No. 4 (2017) of the Committee on the Protection of the Rights of All Migrant Workers and Members of Their Families and No. 23 (2017) of the Committee on the Rights of the Child on State obligations regarding the human rights of children in the context of international migration in countries of origin, transit, destination and return, 16 November 2017, CMW/C/GC/4-CRC/C/GC/23, para. 11.

16 United Nations Human Rights Committee, 13 November 2002, Communication No. 900/1999, CCPR/C/76/D/900/1999, para. 8. 2.

17 PACE resolution 1810 (2011), 15 April 2011, Unaccompanied children in Europe: issues of arrival, stay and return, available at: http://assembly.coe.int/nw/xml/XRef/Xref-XML2HTML-en.asp?fileid=17991 (accessed on $5^{\text {th }}$ November 2018).

18 Cf. ibid, para. 5. 9.

19 Available at: http://website-pace.net/web/apce/children-in-detention (accessed on $5^{\text {th }}$ November 2018). 
detain a person in the asylum procedure. This requirement is applicable to all individuals irrespective of their age.

The basic regulation is in the Reception Directive ${ }^{20}$ that sets up conditions for reception of applicants for international protection. In the paragraph 18 of its preamble it refers to the Convention on the Rights of the Child. According to this paragraph, applicants in detention must be treated with respect for their human dignity and measures should be specifically designed to meet their needs. The Member States should ensure application of art. 37 of the United Nations Convention on the Rights of the Child. ${ }^{21}$ The Reception Condition Directive then defines the detention in its art. 2, letter $\mathrm{h}$ ) as confinement of an applicant by a Member State within a particular place, where the applicant is deprived of his or her freedom of movement. It should be emphasised that the Directive covers detention of applicants for the international protection. ${ }^{22}$ The Reception Directive also contains a definition of a minor in art. 2, letter d) and an unaccompanied minor in letter e). The Directive does not use the term "child" as it does the Convention on the Rights of the Child. It replaces the term by a term often used in national law, namely "a minor". Accordingly, a minor is a third-country national or a stateless person below the age of 18 years.

The Reception Directive contains multiple provisions on detention in its articles 8 to 11. Specifically art. 11 deals with the detention of vulnerable persons and of applicants with special needs, including children regardless of the fact whether accompanied or unaccompanied. ${ }^{23}$ The Reception Directive does not exclude detention of children. In its art. 11 para 2) it admits detention of minors as a last resort measure which may be used only if other less coercive alternative measures cannot be applied effectively. Similarly it requires that the detention must be for the shortest period of time and minors should be placed in a suitable accommodation as soon as possible. ${ }^{24}$

The preamble also clarifies that detention of a minor may be justified only after all non-custodial alternative measures to detention have been duly examined. The aim is to preserve physical and psychological integrity of the applicant, and especially a minor whose development undergoes structural changes. Any alternative measure to detention must respect the fundamental human rights of applicants. ${ }^{25}$

The Reception Directive does not elaborate alternatives to detention that should be applied in relation to children. Children are also covered by the general regulation of art. 8 para 4 of the Reception Directive. This provision stipulates several examples of alternatives to detention such as regular reporting to the authorities, the deposit of a financial guarantee, or an obligation to stay at an assigned place. The obligation to regulate the alternatives to detention is put on Member States

20 Directive 2013/33/EU of the European Parliament and of the Council of 26 June 2013 laying down standards for the reception of applicants for international protection, OJ L 180, 29. 6. 2013, p. 96-116.

21 Cf. para. 18 of the Preamble of Directive 2013/33/EU.

22 The Directive 2013/33/EU is complemented by the Qualification Directive, Directive 2011/95/EU of the European Parliament and of the Council of 13 December 2011 on standards for the qualification of third-country nationals or stateless persons as beneficiaries of international protection, for a uniform status for refugees or for persons eligible for subsidiary protection, and for the content of the protection granted OJ L 337, 20. 12. 2011, p. 9-26 and Procedural Directive, Directive 2013/32/EU of the European Parliament and of the Council of 26 June 2013 on common procedures for granting and withdrawing international protection OJ L 180, 29. 6. 2013, p. 60-95.

23 The art. 21 of the Reception Directive provides an exemplary enumeration of vulnerable persons, including minors, unaccompanied minors or disabled people.

24 See art. 11 para 2 of the Reception Directive.

25 Comp. para 20 of the Preamble of Reception Directive. 
and their legal orders and the alternatives are not, as such, regulated by the EU law. This is despite the fact that the alternatives may be quite an effective tool which can replace the detention.

The Reception Directive is complemented with the Qualification Directive 2011/95/EU ${ }^{26}$ that does not contain any regulation of detention. Next to it there is the Procedural Directive ${ }^{27}$ which has one provision on the detention, namely art. 26. This article just refers to the Reception Directive as concerns the grounds for and conditions of detention and the guarantees available to detained applicants. $^{28}$

\section{DECISION-MAKING PROCEDURE ON DETENTION}

\subsection{Legal basis and grounds for detention}

Any deprivation of liberty must be prescribed by law. This is required both by art. 5 para 1 of the European Convention, international agreements ${ }^{29}$ as well as case law of the ECtHR and the EU Court of Justice (CJEU). ${ }^{30}$ The case law of both courts made it clear that the national legislation allowing deprivation of liberty must be sufficiently accessible, precise and foreseeable in its application to avoid all risk of arbitrariness. ${ }^{31}$

Any detention must be well grounded. The European Convention enumerates the grounds in art. 5 para 1 which specifically in letter $\mathrm{f}$ ) regulates detention of migrants. In this provision the Convention allows detention of a person to prevent an unauthorised entry into the country or of a person against whom an action is being taken with a view to deportation or extradition. ${ }^{32}$ Another ground is formulated in letter b) of the same article according to which the arrest or detention is lawful in case of non-compliance with the order of a court or in order to secure the fulfilment of any obligation prescribed by law. ${ }^{33}$

The EU Reception Directive enumerates grounds for detention in art. 8 para 3. These grounds make a closed list ${ }^{34}$ and EU Member States are not allowed to go beyond the grounds set up in this provision. At the same time, EU Member States are bound to introduce the grounds in their national legislation. The grounds can be characterised as general and do not make any difference between detention of adults and children.

26 Directive 2011/95/EU of the European Parliament and of the Council of 13 December 2011 on standards for the qualification of third-country nationals or stateless persons as beneficiaries of international protection, for a uniform status for refugees or for persons eligible for subsidiary protection, and for the content of the protection granted, OJ L 337, 20. 12. 2011, p. 9-26.

27 Directive 2013/32/EU of the European Parliament and of the Council of 26 June 2013 on common procedures for granting and withdrawing international protection OJ L 180, 29. 6. 2013, p. 60-95.

28 See art. 26 of Directive 2013/32.

29 For example, art. 9 para 1 of International Covenant on Civil and Political Rights or art. 37 letter b) of The Convention on the Rights of the Child.

30 See for example judgement of CJEU in C-528/15, Policie ČR, Krajské ředitelství policie Ústeckého kraje, odbor cizinecké policie proti Salah Al Chodor a ostatní, ECLI:EU:C:2017:213, para 38.

31 See the ECtHR, Del Río Prada v. Spain, no. 42750/09, 21 October 2013, para 125.

32 See Art. 5. para 1 letter $\mathrm{f}$ ) of the European Convention on Human Rights.

33 See ibid, art. 5. para 1 letter b).

34 Cf. wording of art. 8 para. 3 of the Reception Directive according to which an applicant may be detained only on the grounds enumerated there. 
The Reception Directive allows detention in order to check the identity or nationality of the applicant for international protection. The detention may be justified also by the necessity to clarify circumstances on which the application for international protection is founded and by the necessity to get the information which could not be acquired without the detention, especially if there is a risk of absconding of the applicant. The applicant for international protection may be detained also during the procedures dealing with the right of entry of the applicant. The Member States may decide on the detention also in the procedures based on the Return Directive ${ }^{35}$ if other specific conditions are fulfilled. Specifically, a detention is allowed if required by the necessity to protect national security and public order. Finally, under the Reception Directive, a detention is allowed in situations presumed in art. 28 of the Dublin III Regulation. ${ }^{36}$

In this context it is important to point out to the relation between grounds for detention in the European Convention and the Reception Directive. Five out of six grounds for detention in the Reception Directive are formulated in art. 5 para 1, letter $\mathrm{f}$ ) of the European Convention. ${ }^{37}$ The only reason for detention which is explicitly covered only in the Reception Directive and is not contained in European Convention is the detention based on national security and public order grounds. This fact can lead to a differing interpretation as for the compatibility of national regulations with the standards of the EU law. ${ }^{38}$

\subsection{Necessity and proportionality of detention}

The evaluation of necessity and proportionality of the detention $v i s-\grave{a}$-vis an individual applicant for international protection, irrespective of age, must be done by the competent state authorities. The evaluation must be individualised and any decision on migrant children must respect their best interests. The state authorities are obliged to check whether the detention is the last resort solution. If children are accompanied by parents, it is necessary to respect their right to family life. The detention is allowed only for the necessary time period and living conditions in the detention centre must meet the interests and needs of children. ${ }^{39}$

The above mentioned standards were set up in the case-law of the ECtHR and many of them were formally introduced in EU law. Although the European Convention and EU regulation seem very similar, it is different as far as the necessity test is concerned. ${ }^{40}$ The necessity test is regulated in EU secondary law, especially in asylum legislation. ${ }^{41}$ The test was inserted in the art. 8 para 2 of the Reception Directive. The authorities of Member States may detain the applicant if it is not possible to apply other, less coercive rules. ${ }^{42}$ On the other hand, the European Convention does not regulate

35 Directive 2008/115/EC of the European Parliament and of the Council of 16 December 2008 on common standards and procedures in Member States for returning illegally staying third-country nationals, OJ L 348, 24. 12. 2008 , p. $98-107$.

36 Regulation (EU) No 604/2013 of the European Parliament and of the Council of 26 June 2013 establishing the criteria and mechanisms for determining the Member State responsible for examining an application for international protection lodged in one of the Member States by a third-country national or a stateless person, OJ L 180, 29. 6. 2013, p. 31-59.

37 Cf. European Union Agency for Fundamental Rights (FRA), European legal and policy framework on immigration detention of children. Luxembourg: Publications Office of the European Union, 2017, available at: fra.europa.eu (accessed on $5^{\text {th }}$ November 2018), p. 44.

38 See ibid.

39 See ibid, p. 47 and following.

40 Ibid.

41 The necessity test can be found in the Return Directive in art. 15 para. 1.

42 See art. 8 para. 2 of the Reception Directive. 
the necessity test. However, if the law of the contracting parties contains the necessity test, they are bound by the ECtHR case law to use it. ${ }^{43}$ Anyway, irrespective of the case-law of the ECtHR, the EU Member States are bound to apply the necessity test.

The EU Member States have the obligation to determine whether a detention of an individual child is a last resort solution. ${ }^{44}$ The process is composed of three basic steps based on the full respect to the rights of the child. First of all, the child should be placed in a reception centre or other open facility, with the necessary support to guarantee the child's well-being. Second, if the restriction of fundamental rights is necessary (usually only restriction of personal liberty), the authorities should set up for example the obligation of regular reporting or designated residence. Furthermore, it is recommended to manage the case so as to adapt the procedure with respect to the child. The result of the procedure must respect most suitable alternative. Third, if the purpose of the procedure cannot be reach by alternative means, the authorities may order a detention. ${ }^{45}$ A lacuna in the national regulation of alternatives to detention may not excuse the detention of the person concerned. ${ }^{46}$

It should be emphasised that there is a plethora of alternatives to detention and most of them only limit, but not deprive the freedom of movement. ${ }^{47}$

\subsection{Procedural safeguards}

Another condition crucial for setting up legality and non-arbitrariness of detention is the evaluation of procedural safeguards of a child in asylum procedure. In general, the procedural safeguards are applied irrespective of the age of the applicant. One of the procedural safeguards is also the judicial review which is set up in international law, ${ }^{48}$ in the European Convention, ${ }^{49}$ both in primary ${ }^{50}$ and secondary ${ }^{51}$ EU law. Among other safeguards set up in EU law belongs the right for free legal assistance and representation, as well as language assistance in a language which the applicant understands or is reasonably supposed to understand. ${ }^{52}$

The general procedural safeguards are complemented by special procedural safeguards justified by the legal dependence and immaturity of the child. The special procedural safeguards are express in the requirement of information duty in an appropriate form and adaptation of the asylum procedure for special needs of children. Adjacently there is an obligation of a Member State to nominate a guardian - a natural or legal person - that would guard the interests of the child. ${ }^{53}$

43 ECtHR, Rusu v. Austria, no 34082/022, 2 October 2008, para. 54-59.

44 FRA, European legal and policy framework on immigration detention of children. Luxembourg: Publications Office of the European Union, 2017.

45 See FRA, European legal and policy framework on immigration detention of children. Luxembourg: Publications Office of the European Union, 2017, p. 49.

46 Ibid.

47 Examples will be given further on in this article.

48 Art. 9 para. 4 of the International Covenant on Civil and Political Rights.

49 Art. 5 para. 4 of the European Convention on Human Rights.

50 Art. 47 of the Charter of Fundamental Rights of the European Union, OJ C 326, 26. 10. 2012, p. 391-407.

51 Art. 9 para. 3 of the Reception Directive, but also art. 15 para. 2 of the Return Directive.

52 See art 9 para 4 of the Reception Directive.

53 FRA, European legal and policy framework on immigration detention of children. Luxembourg: Publications Office of the European Union, 2017, p. 66 and following. 
The EU secondary legislation, namely art. 23 of the Reception Directive, emphasises the principle of the best interest of the child. ${ }^{54}$ The Member States are obliged to ensure that the interests of the child would be a primary consideration in their implementation of the Reception Directive. The best interests of child are also reflected in the principle of participation embodied in art. 23, para 2 letter d). National authorities are obliged to take into consideration view of minors with respect to their age and maturity. This is one of the obligations which Member States cannot disregard when deciding the best interests of the child. This obligation is applicable also where the detention of a child - applicant for the international protection - is considered. The EU Member States often transposed the EU secondary rules without an explicit referral to the requirement that the child should be heard. Still, some state authorities must respect this condition set up in national rules according to which a child cannot be detained if he/she was not heard by a judge. ${ }^{55}$

The participatory right of the child is based on the art. 12 of the Convention on the Rights of the Child. This participatory right also includes the right of the child to get the information on the detention. This information must be given to the child in an appropriate manner. If the child is detained with the family, it may be presumed that the information will be given by the parents or adult members of the family. Therefore, there are no specific provisions or practices regulating the way how the child should be informed. Anyway, the information should be communicated to the child in an appropriate manner. ${ }^{56}$ If the detention concerns an unaccompanied child, all the necessary information on the child's legal status should be communicated by the guardian.

The UN Committee on the Rights of the Child recommends ${ }^{57}$ that a competent guardian should be appointed to every unaccompanied or separated child as expeditiously as possible. ${ }^{58}$ The asylum procedures should continue after the guardian is appointed. If a child undergoes administrative or asylum procedures, he/she should be provided with a legal representative in addition to a guardian. ${ }^{59}$ The legal representative defences the rights and interest of child in every formal procedure.

The task of the guardian is to fulfil three functions, namely, ensure the well-being of the child, protect his/her best interests as well as to exercise the general legal representation and complement the child's limited legal capacity. ${ }^{60}$ By this the guardian differs from the qualified lawyer or other legal expert. This qualified lawyer gives a legal assistance to the child and acts on their behalf. It represents the child in administrative or judicial proceedings, especially in criminal, asylum or other procedures based on national legislation. ${ }^{61}$

54 VAN OS, C.: The Best Interests of the Child Assessment with Recently Arrived Refugee Children. In: SORMUNEN, M. (ed.): The Best Interests of the Child - A Dialogue between Theory and Practice. Strasbourg: Council of Europe Publishing, 2016, p. 70-71.

55 FRA, European legal and policy framework on immigration detention of children, Luxembourg: Publications Office of the European Union, 2017, p. 64-65, for example Finland.

56 Ibid. p. 65-66.

57 UN Committee on the Rights of the Child (CRC), General comment No. 6 (2005), Treatment of Unaccompanied and Separated Children Outside their Country of Origin, 1 September 2005, CRC/GC/2005/6, para. 21.

58 Ibid.

59 Ibid.

60 Cf. European Union Agency for Fundamental Rights: Guardianship for children deprived of parental care: A handbook to reinforce guardianship systems to cater for the specific needs of child victims of trafficking, Luxembourg: Publications Office of the European Union, 2014.

61 Cf. ibid, p. 15. 


\subsection{Dignity and human conditions}

Both the EU law and the European Convention on Human Rights require that the conditions in detention should be human and with respect to dignity of the detained person. The Reception Directive sets up in art. 10 and 11 the conditions for detention of applicants for international protection. The para 18 of the Preamble of this directive requires that the applicants who are in detention should be treated with full respect for human dignity and their detention should be specifically designed to meet their needs in that situation. ${ }^{62}$ These needs include in relation to children especially necessary health treatment, but also access to education and leisure activities, the preservation of the unity of the family and adequate accommodation respecting its privacy. ${ }^{63}$

The crucial impact on the improvement of conditions in detention centres was effected by the case-law of the ECtHR, this being true not exclusively in relation to children, but to all detained persons irrespective of age. In relation to the detention of children, the ECtHR repeatedly found a breach of art. 3 and art. 5, para. 1, letter f) and eventually of art. 8 of the European Convention, as far as concerns conditions in the detention centres. ${ }^{64}$ The Court concluded that the detention of a child (even if accompanied by a parent) in a closed environment can rise feelings of anxiety and can endanger their development. ${ }^{65}$ In a later case the ECtHR added that also in the child-friendly environment the conditions inherent to the detention centre may represent a significant source of stress and anxiety. ${ }^{66}$ The ECtHR further ruled that if the conditions in the detention centre - especially accommodation, hygiene or infrastructure - would be seriously bad then the detention would breach the Convention even though it would last only for two days. ${ }^{67}$

\section{ALTERNATIVES TO DETENTION}

\subsection{Alternatives to detention of children in the case-law of ECtHR}

Neither the European Convention nor the EU law gives any definition of the alternatives to detention. ${ }^{68}$ In practice more definitions are used; most often the definition created by global network of non-governmental organisations and individuals called International Detention Coalition. ${ }^{69}$ Thereby as an alternative to detention is to be considered "any law, policy or practice by which persons are not detained for reasons relating to their migration status." 70

62 Ibid.

63 Art. 11, para. 1-4 of the Reception Directive 2013/33/EU.

64 See for example ECtHR, Popov v. France, no. 39472/07 and 39474/07, 19 January 2012 or ECtHR, Mubilanza Mayeka and Kaniki Mitunga v. Belgium, no. 13178/03, 12 January 2007.

65 Cf. ECtHR, Muskhadzhiyeva and others v. Belgium, no. 41442/07, 19 January 2010, para. 34.

66 Cf. ECtHR, A. B. and others v. France, no. 11593/12, 12 July 2016, para. 144.

67 ECtHR, Rahimi v. Greece, no 8687/08, 5 July 2011, para. 110.

68 DE BRUYCKER, Ph. - BLOOMFIELD, A. - TSOURDI, E. - PÉTIN, J.: Alternatives to Immigration and Asylum Detention in the EU., p. 86. Available at: http://odysseus-network.eu (accessed on $5^{\text {th }}$ November 2018).

69 SAMPSON, R. - CHEW, V. - MITCHELL, G. - BOWRING, L.: There Are Alternatives: A Handbook for Preventing Unnecessary Immigration Detention (Revised). Melbourne: International Detention Coalition, 2015, p. II.

70 Ibid, p. II. 
The basic argument in favour of alternatives to detention is based on the human rights protection, especially the right to personal liberty. The alternatives to detention are against no internal law obligation guaranteeing the right of a child. ${ }^{71}$ The second argument is of a pure economic nature. ${ }^{72}$ The alternatives to detention are less expensive than the detention. Third, it is often confirmed that alternatives are more effective means as far as concerns the cooperation, participation and involvement of children if they are used in the appropriate way. ${ }^{73}$ Last but not least, the alternatives to detention less intrude into psychological as well as physical development of the child. ${ }^{74}$

Finally, it may be emphasised that the decision-making practice of the ECtHR leads to the conclusion that the Contracting Parties of the Convention should offer alternatives to detention. Thus, the states are bound to put them into their legislation and should consider them in an individual case. According to the case-law of the ECtHR the principle of the best interest of a child includes the obligation to deliberate on all alternatives to detention. ${ }^{75}$ In case the state authorities do not properly investigate the situation of the child and do not verify if the detention is a last resort solution, they breach the right of the child to liberty ${ }^{76}$ In this regard the ECtHR concluded that if the state authorities do not verify whether an alternative measure would be available, they would detain the child without a proper justification and would breach its Convention obligations. ${ }^{77}$

\subsection{Examples of the alternatives to detention}

Most European states did not introduce special alternatives to detention of children. ${ }^{78}$ At the same time, there are known and practiced alternatives which are especially appropriate for the families with children, particularly for the separated or unaccompanied children. Alternatives must be adapted to the character and content of the legal system of each country. ${ }^{79}$ The introduction of the alternatives to detention and their application should avoid as far as possible the recourse to the institutional solution. In this regard it is advisable that the guardianship system, as an alternative for detention, would be sufficiently developed. ${ }^{80}$ The individualised approach is a key solution to the migration situations. ${ }^{81}$

Foster care. The system of the foster care is often a preferable model for alternatives to detention of unaccompanied or separated children. The foster care creates a favourable environment where the child can develop harmoniously. The separated child receives the care, protection and support as in a family. ${ }^{82}$ The system of foster care is introduced in a number of European states. Thus, for

71 Conference Report: Immigration Detention of Children: Coming to a Close?, p. 44.

72 Cf. PERELMAN, Ch.: Právna logika. Bratislava: Kalligram, 2014, p. 86.

73 Cf. ibid.

74 Cf. ibid.

75 ECtHR, Popov v. France, no. 39472/07 and 39474/07, 19 January 2012, para. 119.

76 Ibid, para 121.

77 Cf. ECtHR, A.B. v. France, no. 11593/12, 12 June 2016, para. 124-125; ECtHR, R.M. and M.M. v. France, no. 33201/11, 12 June 2016, para. 87, ECtHR, A.M. and others v. France, no. 24587/12, 12 June 2016, para. 93-95; ESLP, R.K. v. France, no. 68264/14, 12 June 2016, para. 113-115, ESLP, Rahimi v. Greece, no. 8687/08, 5 July 2011.

78 FRA, European legal and policy framework on immigration detention of children. Luxembourg: Publications Office of the European Union, 2017, p. 51.

79 Conference Report: Immigration Detention of Children: Coming to a Close?, p. 34.

80 UNGA, resolution 64/142, A/RES/64/142, Guidelines for the Alternative Care of Children, 24 February 2010

81 Conference Report: Immigration Detention of Children: Coming to a Close?, p. 35.

82 Ibid. 
example in the Italian region Venice the authorities first ask the child if his/her relatives or family friends live in the region. If not, the authorities place the child in the institutional/residential care. If after the evaluation of the needs of the child is becomes clear that the child should live in an alternative family-like environment, suitable foster families are found. These foster families are of the same cultural background, often of Italian nationality. Under this set-up the communication should not be problematic with the creation of own communication channels. ${ }^{83}$

Kinship Care. This alternative is based on the fact that the child shares the place with the members of the extended family or stay with close friends of the family. The condition is that the child knows the friends. Thus for example in Sweden there is a relatively high number of unaccompanied children placed in the kinship care. ${ }^{84}$ In these cases the Swedish authorities check these families and eventually train them before the placement. A research in Sweden has shown that the kinship care gives more stability than the placement in foster families or institutionalised care. In comparison to other alternatives, the kinship care option supports a good communication with the child and the carer who is a relative or familiar to the child. The communication with the child is supported also by the common language. Similarly this care supports cultural identity of the child. ${ }^{85}$

Accommodation Centre for Children (institutionalised care). A placement of an unaccompanied child in a specialised open centre is practiced in Lithuania and Slovenia. The Slovenian law sets up that on condition of an agreement with the guardian an unaccompanied child may be placed in an adequate centre for children. The application of this legislation is conditioned by the real possibilities; thus, for the time being, this possibility was not used and in Slovenia no such centre has been established, yet. ${ }^{86}$ On contrary, in Lithuania all children are placed in an open facility which, however, is not specifically designed for children. This facility is used for accommodation of persons with the refugee status, irrespective of their age. Still the establishment of this non-specialised centre in Lithuania led to a favourable situation for separated children who contrary to Slovenia are not detained at all. ${ }^{87}$

\subsection{Alternatives to detention of families with children}

When detaining families with children it is necessary to take into consideration their right to private and family life. It is undisputable that families can better live without any detention. Therefore, it is necessary that states would search for alternatives to detention also in relation to the families with children. The right to family life includes also the rights of children to live together with their parents and also the right for protection against any interference to the family life. ${ }^{88}$ The ECtHR

83 Ibid, p. 36.

84 Approximately $40 \%$ of children.

85 Conference Report: Immigration Detention of Children: Coming to a Close?, p. 36.

86 DE BRUYCKER, Ph. - BLOOMFIELD, A. - TSOURDI, E. - PÉTIN, J.: Alternatives to Immigration and Asylum Detention in the EU, p. 101. Available at: http://odysseus-network.eu (accessed on $5^{\text {th }}$ November 2018).

87 Ibid.

88 Art. 8 of the European Convention and art. 7 of the EU Charter. For the principles of application of EU Charter also in relation to national courts see for example: HAMULÁK, O. - MAZÁK, J.: The Charter of Fundamental Rights of the European Union vis-à-vis the Member States - Scope of its Application in the View of the CJEU. In: Czech Yearbook of Public \& Private International Law, vol. 8, 2017, pp. 161-172; KERIKMÄE, T. - HAMULÁK, O. - CHOCHIA, A.: A Historical Study of Contemporary Human Rights: Deviation or Extinction? In: Acta Baltica Historiae et Philosophiae Scientiarum, Vol. 4, 2016, No. 2, pp. 98-115. 
concluded that the best interests of the child cannot be limited to keeping the family together. The state authorities are obliged to take all necessary measures to limit the detention of families with children and effectively preserve the right to family life. ${ }^{89}$

Open centres for families with children. Open centres for families with children are established in a number of European states. Such open centres became one of the first alternatives to detention introduced in the Netherlands. These centres preserve the right to family life, however, with the confinement to the area of the municipality. The adult family members have the obligation to report to local authorities once a week. The representatives of non-governmental organisations have unlimited access to these centres. ${ }^{90}$

Despite this fact the Netherlands recently opened a closed centre for families with the children. Its purpose is to prepare the return of the third country nationals to the countries of origin. Still, the specialised centre has its aim to as far as possible reduce the impression of the fact that it detains family members. The centre is not separated from its neighbourhood by the barbed wire. The centre offers a kitchen, living room and bedrooms. During the stay an emphasis is put on the accessible education, health care and other public services.

In Austria the accommodation of families with children is secured on the outskirts of Vienna. The authorities decide about the alternative to detention in a selected accommodation centre or a regular reporting of adult family members. Both alternatives may be combined. ${ }^{91}$ Families with the children can freely move; non-governmental organisations have also a free access to assist the families. There are no uniformed officers in the building. Still, the possibility to detain the family is still preserved, especially in case of its return to the country of origin. ${ }^{92}$

Belgium established a possibility for the families with children to be accommodated in open centres ${ }^{93}$ with the support of social workers. This practice was introduced after several proceedings before ECtHR against Belgium. ${ }^{94}$ The conditions in these facilities respect privacy and are adjusted to respect family life and needs of children. The families are obliged to stay inside the accommodation during night and morning periods. ${ }^{95}$ Otherwise they are free to move. Children are enrolled to local schools and the families can freely have visitors in their accommodation. ${ }^{96}$

During their stay the families are supported by "coaching" from the immigration office. ${ }^{97}$ The presence of the coach should help the family to find a permanent solution to their status in the receiving country or return to the country of their origin. This person also prepares various meetings (medical treatment, school, legal representation pro bono, etc.) and sees to everyday logistic, administrative or medical support to the families. The expenses, including coupons for purchase of food and other items from supermarkets, is covered by the immigration office and are partially subsidised by the European Return Fund. ${ }^{98}$

89 ECtHR, Popov v. France, no. 39472/07 and 39474/07, 19 January 2012, para. 147.

90 Conference Report: Immigration Detention of Children: Coming to a Close?, p. 37.

91 Ibid, p. 37.

92 Ibid, p. 38.

93 UNHCR, Global Strategy Beyond Detention 2014-2019. Goal 1: Ending the detention of children, Options paper 1, p. 15.

94 ECtHR, Mubilanza Mayeka a Kaniki Mitunga v. Belgium, no. 13178/03, 12 January 2007; FRA, European legal and policy framework on immigration detention of children. Luxembourg: Publications Office of the European Union, 2017 , p. 51.

The period from 9 o'clock in the evening until 9 o'clock in the morning.

96 UNHCR, Global Strategy Beyond Detention 2014-2019. Goal 1: Ending the detention of children, Options paper 1, p. 15.

97 Ibid.

98 For activities of European Return Fund in individual EU countries, see https://ec.europa.eu/home-affairs/financing/ fundings/migration-asylum-borders/return-fund/national-actions_en (accessed on $5^{\text {th }}$ November 2018). 
Belgium made a public announcement in October 2017 that due to a massive influx of migrants it was going to re-establish the detention of children. It made this step despite large protests of nongovernmental organisations in the country. Following the announcement in 2017 Belgium started to build a new closed centre for families with children. It was finished in summer 2018 and since then it is used for detention of families with children.

Individual case management. The proper solution for families with children very often requires cooperation with organisations that provide applicants with various services. The social worker leads the family and is responsible for the chosen solutions. Together with the family members the social worker choses social services and counselling from the organisations and institutions which may help the family. Poland introduced a pilot project of a non-governmental organisation for vulnerable persons (especially families with children which were either released from detention or imposed alternatives to detention). The project offered services connected with the engagement of these individuals in immigrations procedures, including the return procedures. ${ }^{99}$ The aim of the project was to give support to families and develop the trust procedures. The project also made accessible legal and psychological support.

\section{CONCLUSIONS}

The aim of this article was to analyse conditions which European states must fulfil so that the detention of a child would not be proclaimed unlawful and arbitrary. Even though the international community is in agreement that the detention of children both in asylum and return procedures should not be executed, European states still practice it. Some states even return to this practice.

The conditions include the obligation of states to have a clear legal basis for detention in their legal orders. Moreover, the detention must be based on the regulated grounds for detention that are rooted especially in EU law. Furthermore, the detention should be necessary and proportionate as is required by the EU law as well as the case-law of the ECtHR. Thus, European states are obliged to examine the possible alternative solutions to detention. They also have to respect procedural safeguards, including special procedural safeguards applicable in relation to children. These safeguards include a necessity of appropriate communication with a child and assignment of a guardian. Finally, states must secure dignified and human conditions in the detention centre.

Correspondingly, it is clear that European states are obliged to fulfil quite a high number of conditions in order to ensure that the detention of children would not be unlawful and arbitrary. In this regard it is surprising that European states are not eager to use more alternatives to detention even though their benefits are undisputable. While some progress can be seen in this respect, the discussion on alternatives to detention of children in asylum centres is topical and substantial. This discussion can influence especially the attitudes of states that still detain children (accompanied or unaccompanied) in asylum centres.

99 Conference Report: Immigration Detention of Children: Coming to a Close?, p. 40-41. 


\section{Bibliography:}

BARRETO, Th. R.: Human Rights of Refugee Children in Light of Multilevel System. Europa-Kolleg Hamburg, Institute for European Integration, Study Paper No 02/18, 2018. 135 p. Available at: https://europa-kolleg-hamburg. de/wp-content/uploads/2018/03/SP-02-18_Thais-Rivera_MR.pdf (accessed on $5^{\text {th }}$ November 2018).

DE BRUYCKER, Ph. - BLOOMFIELD, A. - TSOURDI, E. - PÉTIN, J.: Alternatives to Immigration and Asylum Detention in the EU. 157 p. Available at: http://odysseus-network.eu (accessed on $5^{\text {th }}$ November 2018).

HAMULÁK, O. - MAZÁK, J.: The Charter of Fundamental Rights of the European Union vis-à-vis the Member States - Scope of its Application in the View of the CJEU. In: Czech Yearbook of Public \& Private International Law, vol. 8, 2017, pp. 161-172.

KERIKMÄE, T. - HAMULÁK, O. - CHOCHIA, A.: A Historical Study of Contemporary Human Rights: Deviation or Extinction? In: Acta Baltica Historiae et Philosophiae Scientiarum, Vol. 4, 2016, No. 2, pp. 98-115.

PERELMAN, Ch.: Právna logika. Bratislava: Kalligram, 2014, 274 p.

SAMPSON, R. - CHEW, V. - MITCHELL, G. - BOWRING, L.: There Are Alternatives: A Handbook for Preventing Unnecessary Immigration Detention (Revised). Melbourne: International Detention Coalition, 2015, 116 p.

SORMUNEN, M. (ed.): The Best Interests of the Child - A Dialogue between Theory and Practice. Strasbourg: Council of Europe Publishing, 2016, $160 \mathrm{p}$.

VAN OS, C.: The Best Interests of the Child Assessment with Recently Arrived Refugee Children. In: SORMUNEN, M. (ed.): The Best Interests of the Child - A Dialogue between Theory and Practice. Strasbourg: Council of Europe Publishing, 2016, $160 \mathrm{p}$.

\section{Electronic resources:}

European Union Agency for Fundamental Rights (FRA), European legal and policy framework on immigration detention of children. Luxembourg: Publications Office of the European Union, 2017 Available at: fra.europa.eu (accessed on $5^{\text {th }}$ November 2018).

UN Committee on the Rights of the Child (CRC), General comment No. 6 (2005), Treatment of Unaccompanied and Separated Children Outside their Country of Origin, 1 September 2005, CRC/GC/2005/6. Available at: https:// www.refworld.org/docid/42dd174b4.html (accessed on $5^{\text {th }}$ November 2018).

European Union Agency for Fundamental Rights (FRA): Guardianship for children deprived of parental care: A handbook to reinforce guardianship systems to cater for the specific needs of child victims of trafficking. Luxembourg: Publications Office of the European Union, 2014. Available at: fra.europa.eu (accessed on $5^{\text {th }}$ November 2018).

Conference Report: Immigration Detention of Children: Coming to a Close?, Prague 25-26 September 2017, elaborated by the Office of the Czech Government Agent before the European Court of Human Rights, Ministry of Justice of the Czech Republic, on the basis of the presentations given and discussions held during the Conference. Available at: https://rm.coe.int/immigration-detention-of-children-coming-to-a-close-prague-25-26-septe/16807b8841 (accessed on $5^{\text {th }}$ November 2018).

United Nations General Assembly (UNGA), resolution 64/142, A/RES/64/142, Guidelines for the Alternative Care of Children, 24 February 2010. Available at: https://www.unicef.org/protection/alternative_care_Guidelines-English. pdf (accessed on $5^{\text {th }}$ November 2018).

United Nations Refugee Agency (UNHCR), Global Strategy Beyond Detention 2014-2019. Goal 1: Ending the detention of children, Options paper 1. Available at: https://www.unhcr.org/57b5839b7.pdf (accessed on $5^{\text {th }}$ November 2018). 


\section{Contact information:}

Irena Drdúlová, Ph.D. candidate

irena.drdulova@upol.cz

Palacký University in Olomouc

Faculty of Law

17. listopadu 8

77111

Olomouc

Czech Republic

Associate professor Dr. Václav Stehlík

vaclav.stehlik@upol.cz

Palacký University in Olomouc

Faculty of Law

17. listopadu 8

77111

Olomouc

Czech Republic 